\title{
VARIABILITY OF OLIVE OIL CULTIVAR ON STABILITY DURING STORAGE
}

\author{
M.A. Neves ${ }^{\mathrm{a}}$, M.G. Miguel ${ }^{\mathrm{a}, \mathrm{b} *}$, L.G. Pedro ${ }^{\mathrm{b}}$, J.G. Barroso ${ }^{\mathrm{b}}$, A.C. Figueiredo ${ }^{\mathrm{b}}$, \\ D.S. MARTins ${ }^{\mathrm{a}}$ and S.A. DANDLEN ${ }^{\mathrm{a}}$ \\ ${ }^{a}$ Faculty of Sciences and Technology, University of Algarve, Building 8, \\ Campus de Gambelas, 8005-139 Faro. Portugal \\ ${ }^{b}$ Department of Plant Biology, Faculty of Sciences, University of Lisbon, Institute for Biotechnology and \\ Bioengineering, Center for Plant Biotechnology, C2, Campo Grande, 1749-016 Lisbon. Portugal
}

(Received: 19 January, 2010; accepted: 7 April, 2011)

\begin{abstract}
The fatty acid composition and stability of three Portuguese monovarietal olive oils, Cobrançosa, Maçanilha and Verdeal, was studied, maintaining the olive oils at $60^{\circ} \mathrm{C}$ for 75 and 102 days, respectively. Oleic acid was the main fatty acid (64-69\%) in three olive oils cultivars, followed by palmitic acid (15-18\%). The highest percentages of palmitic acid were observed in Maçanilha olive oil (17-18\%). Linolenic acid content was 3\%, on average. Storing the oils at $60^{\circ} \mathrm{C}$ over 75 days did not affect the levels of fatty acids. Cobrançosa and Maçanilha olive oils were more resistant to hydroperoxide formation than Verdeal olive oil, whereas this oil and that of Maçanilha were more resistant to the degradation of those peroxides. Cobrançosa olive oil possessed higher levels of phenols and higher ability for scavenging free radicals than the remaining oils. $\alpha$-Tocopherol content was higher in Cobrançosa and Maçanilha oils than in Verdeal, but a similar high degradation of this vitamin was observed in all oils, disappearing after 5 to 8 days of storage at $60^{\circ} \mathrm{C}$.
\end{abstract}

Keywords: fatty acids, Olea europaea, olive oil, peroxide production, $\alpha$-tocopherol

Olive oil is obtained from the pulp of the stone fruit of the olive tree (Olea europaea L.). Spain, Italy and Greece are the biggest producers of olive oil (Belitz \& Grosch, 1999). Olive oil contains substances such as monounsaturated free fatty acids (e.g. oleic acid), hydrocarbon squalene, tocopherols and phenolic compounds. The traditional Mediterranean diet, rich in virgin olive oil, has been reported as beneficial for preventing cardiovascular disease reducing its major risk factors: hypertension, altered lipoprotein profile, glucose metabolism and thrombotic profile. Olive oil also seems to have a remarkable positive effect on the prevention of cancer and oxidative stress development. Immune function is also positively modulated by olive oil (BAWA, 2007).

The European Union dominates the world production of olive oil (over 70\%), being also its major consumer. Portugal is the fourth largest producer of olive oil in Europe, and the Portuguese olive oil has been recognized as of high quality (CunHA et al., 2006a). In Portugal the most common cooking fat is olive oil and, in the last years, the plantation of olive trees has substantially increased. In spite of the great economical importance of olive oil in Portugal, only recently have some data concerning this subject been internationally published (Gama et al., 2000; Pereira et al., 2002; 2004; Cunha et al., 2005; 2006a, 2006b; MaiA et al., 2007; 2008; Matos et al., 2007).

The quality of olive oil depends on the cultivars and also on the environmental conditions from site to site and from year to year. There are more than 22 cultivars named and

\footnotetext{
* To whom correspondence should be addressed.

Phone: +351289800900; fax: +351289818419; e-mail: mgmiguel@ualg.pt
} 
characterized in Portugal, even though only a small number predominates in each producing region (LEITÃo et al., 1986). In the Algarve region, in the South of Portugal, the main cultivar is Maçanilha Algarvia with big spherical fruits, also very appreciated as green table olives. Other cultivars of unknown origin are cultivated in the region, as a cultivar locally named Verdeal, which is produced regularly and gives an excellent olive oil. Due to increased productivity and pest resistance, other cultivars from other regions of Portugal, such as Cobrançosa were recently introduced in this region. The main goal of the present work was to evaluate the stability of three monovarietal olive oils, obtained from Maçanilha Algarvia, Verdeal and Cobrançosa cultivars, produced in Algarve during 2006 from olives harvested in the same grove and processed in the same way, and relate it with fatty acids, $\alpha$-tocopherol and total phenols contents. This is the first characterization of olive oils produced in the Algarve region.

\section{Material and methods}

\subsection{Olive oil types and sample preparation}

Three cultivars of Portuguese olive oils were used in all experiments: Cobrançosa, Maçanilha and Verdeal. The olive grove was under integrated pest management control. The olives were handpicked when they reached maturity (estimated by colour change and easy fruit detachment), usually at two to three harvest times for each tree. After harvest, olive fruits were carefully stored in ventilated boxes, carried to the mill press and processed at the same day. Olive oils were obtained in the olive grower farm-processing unit. The extraction unit consists of the mill, the thermo beater, and the pulp centrifuge. After being processed in the mill, the oil was separated by decanting, transferred into dark glass bottles, and stored in the dark at $60^{\circ} \mathrm{C}$. Aliquots were periodically taken for analysis.

\subsection{Fatty acid analysis}

Fatty acid methyl esters, for GC analyses, were obtained using methanolic hydrogen chloride. Unsaturated fatty acids double-bond positions were determined by GC-MS mass spectra of their dimethyl disulphide adducts. The samples containing the fatty acid methyl esters were dissolved in $0.2 \mathrm{ml}$ of dimethyl disulfide and $0.05 \mathrm{ml}$ of a solution of iodine in diethyl ether $\left(60 \mathrm{mg} \mathrm{ml}^{-1}\right)$ was added. After $24 \mathrm{~h}$ at room temperature, the mixture was extracted three times with $2 \mathrm{ml}$ of $n$-pentane/ether (1:1). The $n$-pentane/ether fraction was washed with a $5 \%$ sodium thiosulphate solution and evaporated to dryness. The product was taken up in $n$-pentane.

Gas chromatography: GC analyses were performed using a twin FID Perkin Elmer Autosystem XL gas chromatograph, a data handling system and a vaporizing injector port into which two columns of different polarities were installed: a DB-1 fused-silica column (30 $\mathrm{m} \times 0.25 \mathrm{~mm}$ i.d., film thickness $0.25 \mu \mathrm{m}$ ) and a DB-17HT fused-silica column $(30 \mathrm{~m} \times 0.25 \mathrm{~mm}$ i.d., film thickness $0.15 \mu \mathrm{m})$. The oven temperature was programmed, 170 $270{ }^{\circ} \mathrm{C}$ at $5^{\circ} \mathrm{C} \mathrm{min}^{-1}$ and then held isothermally for $5 \mathrm{~min}$; injector and detector temperatures were $300{ }^{\circ} \mathrm{C}$; carrier gas: $\mathrm{H}_{2}$ at $30 \mathrm{~cm} \mathrm{~s}^{-1}$. Samples were injected using the split-sampling technique with a ratio of 1:50. Percentage composition of the samples was computed using the normalization method from the GC peak areas without correction factors. Percentage data shown are mean values of two injections of each sample. 
Gas chromatography-mass spectrometry: The GC-MS unit consisted of a Perkin Elmer Autosystem XL gas chromatograph, equipped with a DB-1 fused-silica column $(30 \mathrm{~m} \times 0.25 \mathrm{~mm}$ i.d., film thickness $0.25 \mu \mathrm{m}$ ) and interfaced with a Perkin-Elmer Turbomass mass spectrometer (software version 4.1). Injector and oven temperature were as described above; transfer line temperature, $280{ }^{\circ} \mathrm{C}$; ion source, $220{ }^{\circ} \mathrm{C}$; carrier gas, He at $30 \mathrm{~cm} \mathrm{~s}^{-1}$; split ratio, 1:40; ionization energy, $70 \mathrm{eV}$; ionization current, $60 \mu \mathrm{A}$; scan range, $40-300 \mathrm{u}$; scan time, $1 \mathrm{~s}$. The identity of the components was assigned by GC-MS data with corresponding data of NIST and of Wiley mass spectral libraries and of laboratory-synthesized components and commercially available FAME standards from a lab-made library.

\subsection{Peroxide value}

A separate mixture of each olive oil and chloroform/acetic acid (3:2) (v/v) was left to react in darkness with saturated potassium iodine solution. The free iodine was titrated with a sodium thiosulphate solution. Peroxide value was determined in milliequivalents of active oxygen per kilogram of oil ( $\left.\mathrm{mEq} \mathrm{O}_{2} \mathrm{~kg}^{-1}\right)$, according to the following formula: $\mathrm{Ip}=10\left(\mathrm{n}_{1}-\mathrm{n}_{2}\right) / \mathrm{m}$ where $\mathrm{n}_{1}$ was the $\mathrm{ml}$ of sodium thiosulphate consumed in sample titration, $\mathrm{n}_{2}$ was the ml of sodium thiosulphate consumed in blank titration and $\mathrm{m}$ was the amount of sample in $\mathrm{g}$ (A.O.C.S, 1989).

\section{4. p-Anisidine value}

p-Anisidine value was determined according to the Portugal Standard (1984) method. Briefly, it was carried out by the determination of the absorbance increase, measured at $350 \mathrm{~nm}$, of a sample solution of $0.5 \mathrm{~g}$ of each olive oil $(\mathrm{m})$ in iso-octane $(25 \mathrm{ml})$, before $\left(A_{1}\right)$ and after reaction with $p$-anisidine $\left(A_{2}\right)$ in glacial acetic acid in the dark. The $p$-anisidine value was determined with the following formula: $25\left(1.2 A_{2}-A_{1}\right) / \mathrm{m}$.

\subsection{Extraction of the polar fraction}

Two grams of each olive oil was extracted with $5 \mathrm{ml}$ of methanol. The mixture was stirred for $1 \mathrm{~h}$ at room temperature and then centrifuged at $4332 \mathrm{~g}$ for $30 \mathrm{~min}$, to separate the polar fraction. The polar methanolic fraction was used for determination of total phenols and for the DPPH scavenging test.

\subsection{Determination of total phenols}

The total phenols content was determined using the Folin-Ciocalteu reagent and gallic acid as standard $\left(5-60 \mu \mathrm{g} \mathrm{ml}^{-1}\right)$. To $2.5 \mathrm{ml}$ of $10 \%$ (v/v) Folin-Ciocalteu reagent, $0.5 \mathrm{ml}$ of sample and $2 \mathrm{ml}$ of sodium carbonate $\left(75 \mathrm{~g} \mathrm{l}^{-1}\right)$ was added. After $30 \mathrm{~min}$ of reaction at room temperature, absorbance was measured at $765 \mathrm{~nm}$ in a Shimadzu 160-UV spectrophotometer.

\subsection{DPPH scavenging test}

A methanolic stock solution $(50 \mu \mathrm{l})$ of each sample was placed in a cuvette, and $2 \mathrm{ml}$ of $60 \mu \mathrm{M}$ 2,2-diphenyl-1-picrylhydrazyl (DPPH) in methanol was added. Absorbance was measured after $10 \mathrm{~min}$, at room temperature, at $517 \mathrm{~nm}$ in a spectrophotometer Ultraspec 1100-pro, Pharmacia. Absorption of a blank sample containing the same amount of methanol and DPPH solution acted as negative control. The percentage inhibition of the DPPH radi- 
cal by the samples was calculated according to the following formula: Scavenging effect $\%=\left[\left(A_{0}-A_{1}\right) / A_{0} \times 100\right.$ where $A_{0}$ was the absorbance of the blank sample and $A_{1}$ was the absorbance in the presence of the sample at each reading time.

\subsection{Determination of $\alpha$-tocopherol content}

The oil samples were diluted with hexane (1:10), $300 \mu 1$ of this solution was transferred to an Eppendorf and $700 \mu \mathrm{l}$ of methanol was added. The samples were vortex-mixed, centrifuged at $3000 \mathrm{~g}$ for $5 \mathrm{~min}$, and the supernatant layer filtered through a $0.45 \mu \mathrm{m}$ filter. The samples were stored at $-20^{\circ} \mathrm{C}$ until HPLC injection.

Tocopherol separations were achieved by HPLC (Beckman, System Gold) using a Purospher column RP-18 (250 $\mathrm{mm} \times 4 \mathrm{~mm} ; 5 \mu \mathrm{m}$ particle size $)$. The mobile phase was a methanol-water solution $(96: 4 \mathrm{v} / \mathrm{v})$ with a flow rate of $2 \mathrm{ml} \mathrm{min}$. The volume of each injection was $20 \mu \mathrm{l}$. Detection was performed at $292 \mathrm{~nm}$ using a detector UV/Vis 166 (Beckman). $\alpha$-Tocopherol was used as standard (3-30 $\left.\mathrm{mg} \mathrm{l}^{-1}\right)$.

\section{Results and discussion}

\subsection{Results}

2.1.1. Fatty acids content. The main fatty acids detected in the three studied cultivars of Portuguese olive oils, stored in the dark, at $60^{\circ} \mathrm{C}$, were palmitoleic, palmitic, linoleic, oleic, linolenic and stearic acids (Table 1).

Oleic acid was, as expected, the dominant fatty acid (64-69\%) detected in similar amounts in each of the studied olive oils (Table 1). The second most important fatty acid was palmitic acid, Maçanilha olive oil showing the highest levels of this fatty acid (17-18\%). In the remaining olive oils, palmitic acid ranged from 15 to $16 \%$. No major variation was observed in the relative amount of any of the olive oils fatty acids during the time of storage.

2.1.2. Olive oil cultivar susceptibility to temperature. Palmitic acid is a saturated fatty acid and as such provides stability along with oleic acid, a monounsaturated fatty acid. In spite of the nutritional benefits of linoleic and linolenic acids, these polyunsaturated fats are susceptible to oxidation. To estimate susceptibility to oxidation, the olive oil was submitted for several days to an accelerated oxidation under standard conditions in order to detect signs of deterioration. In the present work, temperature was $60{ }^{\circ} \mathrm{C}$, and the samples were kept in the dark for 102 days. The degree of oxidation was evaluated by two methods: determining peroxide and $p$-anisidine values. The peroxide concentration reveals the extent of oxidative deterioration of the olive oil. $p$-Anisidine method evaluates the volatile aldehydes content without previous separation from the fat samples. The volatile aldehydes are among the compounds responsible for the rancid aroma of fats.

2.1.3. Peroxide and $\mathrm{p}$-anisidine values. It is noteworthy that at the beginning of the experiment the peroxide values (Fig. 1) had already exceeded the standard value recommended by the International Olive Council ( $<20 \mathrm{mEq} \mathrm{O}_{2} / \mathrm{kg}$ oil) (MAILER, 2006). Verdeal olive oil always showed higher peroxide values than Cobrançosa and Maçanilha olive oils. After 75 days of storage, a decrease of the peroxide values was registered, which can be explained by 


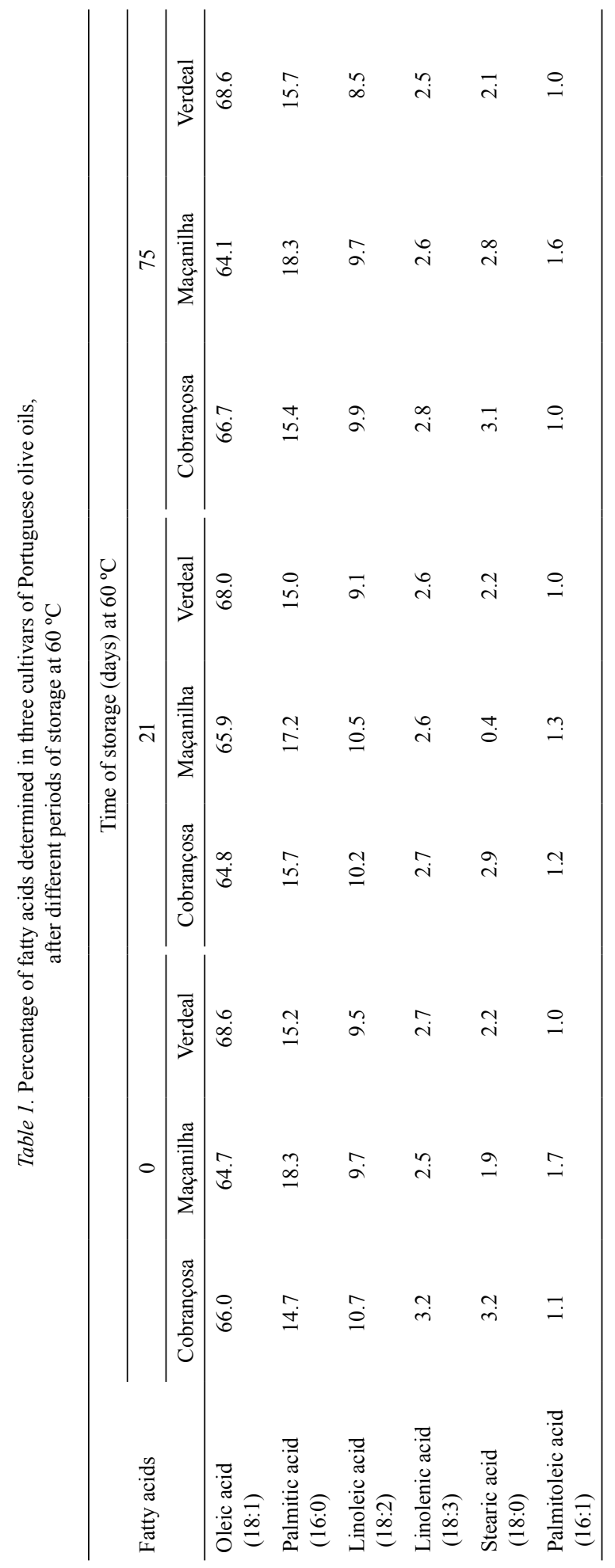


the increase of the $p$-anisidine values (Fig. 2), that is, there was a degradation of peroxides into volatile compounds. In contrast with the results of peroxide values, Maçanilha and Verdeal olive oils showed almost similar $p$-anisidine values over time, with the exception of the last day of sampling in which an accentuated increase was observed for Maçanilha cultivar oil. Cobrançosa olive oil showed in general more volatile aldehydes than the remaining oil samples. This behaviour contradicted with that of peroxide values, in which case, Cobrançosa olive oil generally presented similar peroxide values to that of Maçanilha olive oil.

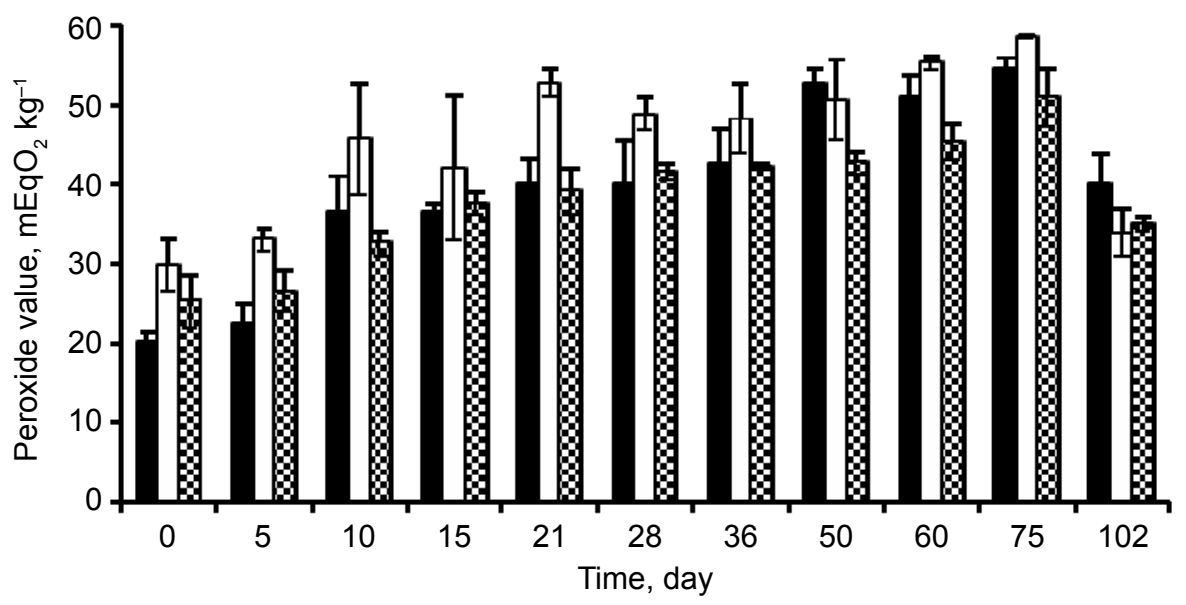

Fig. 1. Peroxide values of the three types of olive oil maintained at $60{ }^{\circ} \mathrm{C}$ for 102 days. The bars indicate standard deviation $(\mathrm{n}=3)$. $\mathbf{\square}$ : Cobrançosa; $\square$ : Verdeal; \$: Maçanilha

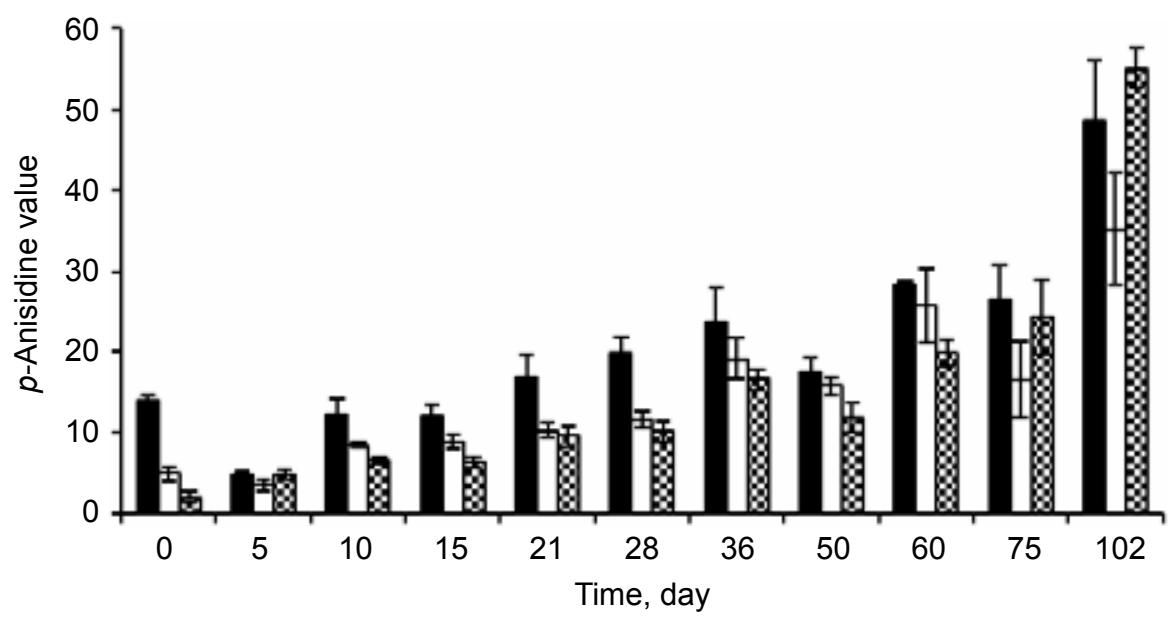

Fig. 2. p-Anisidine values of the three types of olive oil maintained at $60{ }^{\circ} \mathrm{C}$ for 102 days. The bars indicate standard deviation $(\mathrm{n}=3)$. $\square$ : Cobrançosa; $\square$ : Verdeal; \&: Maçanilha 
2.1.4. Determination of total phenol. The total phenol contents of the three monovarietal olive oils (Fig. 3) were very different, not only according to the olive oil variety, but also during the time-course study. The comparison of the olive oils phenol content (Fig. 3) with the corresponding peroxide and $p$-anisidine values (Figs 1 and 2) did not show a clear linear correlation between the stability of the oils and the phenol content. In fact, Maçanilha oil, with its low amount of total phenols, showed similar stability to oxidation as Cobrançosa oil, namely preventing the formation of hydroperoxides. Concerning $p$-anisidine value, Maçanilha olive oil showed better hydroperoxide degradation preventing capacity than Cobrançosa olive oil.

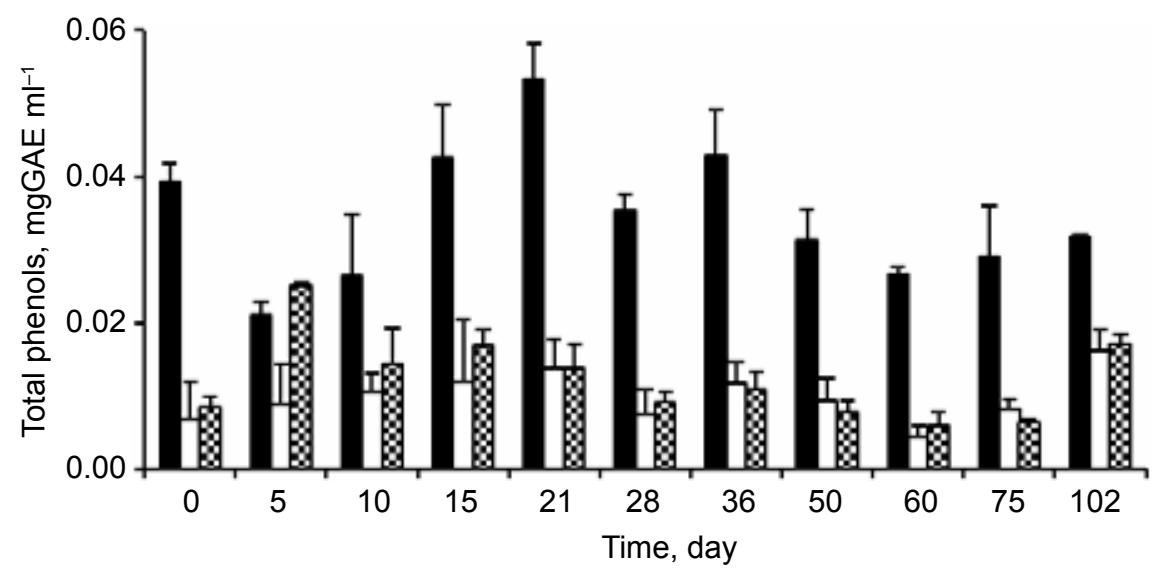

Fig. 3. Total phenols concentration in the olive oils aqueous fraction. The three types of olive oil were maintained at $60{ }^{\circ} \mathrm{C}$ for 102 days. The bars indicate standard deviation (n=3). $\square$ : Cobrançosa; $\square$ : Verdeal; \&: Maçanilha

2.1.5. DPPH scavenging test. The phenolic fraction of all assayed olive oils showed a weak capacity for scavenging free radicals when evaluated by the DPPH method (Fig. 4). Cobrançosa oil showed the highest antioxidant activity. The low antioxidant activity can partly be explained by the low percentages of total phenols found in the oil samples and the best antioxidant activity of Cobrançosa olive oil can be attributed to its highest phenols amounts (Fig. 3). Nevertheless, this relatively higher activity was only observed during the first 21 days of incubation, thereafter a deep decrease of antioxidant activity was observed in all samples.

2.1.6. $\alpha$-Tocopherol content. Tocopherols are the major group of primary antioxidants occurring in vegetable oils and fats. In virgin olive oil about $95 \%$ of the total tocopherol content is $\alpha$-tocopherol. For this reason in the present work only this isomer was quantified in the tested olive oils. $\alpha$-Tocopherol content in the assayed olive oils maintained at $60{ }^{\circ} \mathrm{C}$ (Fig. 5) was within of that already reported for Portuguese olive oils (93-260 mg kg-1) (CuNHA et al., 2006a), although Cobrançosa oil showed higher amounts than the oils of the other cultivars (Fig. 5).

A decrease of $\alpha$-tocopherol was registered up to its complete disappearance after 28 to 36 days of storage at $60^{\circ} \mathrm{C}$. 


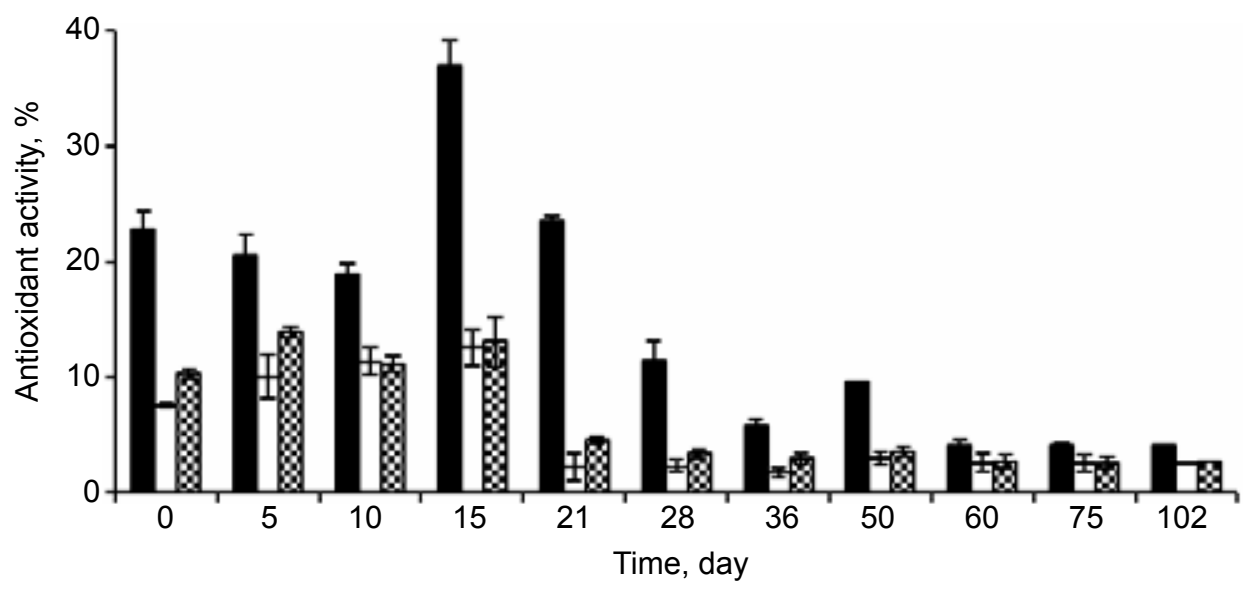

Fig. 4. Antioxidant activity of the olive oils aqueous fractions evaluated by the DPPH method. The three types of olive oils were maintained at $60^{\circ} \mathrm{C}$ for 102 days. The bars indicate standard deviation $(\mathrm{n}=3)$. 口: Cobrançosa; $\square$ : Verdeal; B: Maçanilha

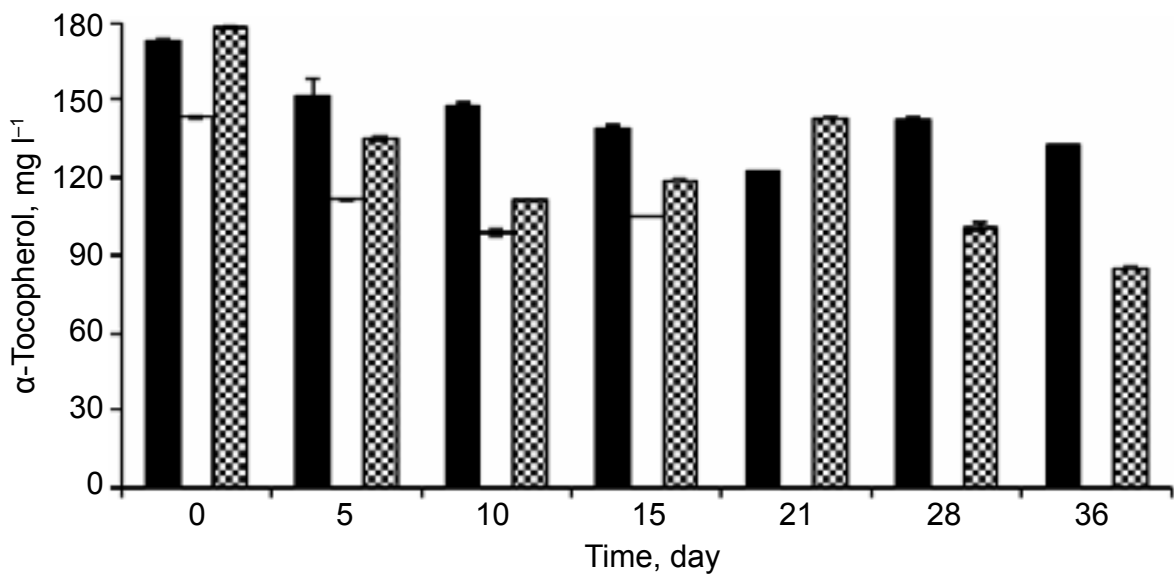

Fig. 5. $\alpha$-Tocopherol content of the olive oils. The three types of olive oil were maintained at $60{ }^{\circ} \mathrm{C}$ for 102 days. The bars indicate standard deviation ( $\mathrm{n}=3$ ). $\mathbf{\square}$ : Cobrançosa; $\square$ : Verdeal; \&: Maçanilha

\subsection{Discussion}

2.2.1. Fatty acids content. Although according to international legislation, linolenic acid content should be $<1.0 \%$ (COMmission ReGULATION, 1991), in the present study, all monovarietal olive oils showed percentages higher than this value. According to MAILER and co-workers (2005) this can often occur in oils from immature olives as the linolenic acid content decreases as the fruit matures, but can also result from a plant stress response (UрснURCH, 2008).

The composition of the fatty acids of the olive oils produced in Algarve showed some characteristics in common, such as lower oleic acid values and higher values of palmitic and linolenic acids than those usually found in olive oils from other regions like Greece or Spain (Aparício \& Luna, 2002; Okogeri \& Tasioula-Margari, 2002). Palmitic acid was in the 
range of values found by OKOGERI and TASIOUla-MARgARi (2002) and LEON and co-workers (2008), although these authors did not find such large amounts of linolenic acid. This can be due to some regional variations, since previous studies on Cobrançosa cultivar olive oil from other regions of Portugal (PEREIRA et al., 2002; SiMÕEs-Lopes et al., 2006) showed different fatty acid composition from that herewith described for Algarve Cobrançosa cultivar, mainly with more oleic acid and less palmitic and linolenic acids relative amounts. The importance of genetic factors on the fatty acid composition of olive oil is well-documented (D'IMPERIO et al., 2007), but the climatic differences between Algarve and the other regions of Portugal, namely milder autumn temperatures and low rainfall during the whole year, may also influence the fatty acid composition. Di BELLA and co-workers (2007) showed an important geographic variation effect on fatty acid composition of olive oils harvested from western and eastern areas of Sicilia. Based on the oleic and palmitic fatty acid composition, the olive oils from Algarve showed characteristics close to some olive oils produced in Tunisia (HADDADA et al., 2007; DAMAK et al., 2008).

The lipidic profile of the olive oils of Algarve may be partly explained by the characteristics of the studied olive grove. As previously shown by APARícIO and LunA (2002), irrigation may contribute to the palmitic acid percentage increase, as well as to the health status of olive trees, which were heavily contaminated with Pseudomonas syringae subsp. savastanoi. As membrane lipid unsaturation, namely the 18:3 content, is a common response in plants to stress, increasing with low temperature, salt and pathogen stresses (UPCHURCH, 2008), the presence of Pseudomonas could be responsible for the high linoleic and linolenic acids contents. A similar effect was found in other plant species after inoculation with Pseudomonas spp. or other pathogens like Phytophthora sojae (KIRSCH et al., 1997; Zou et al., 2005). The increase of linoleic and linolenic and decrease of oleic fatty acids in olive oils as a response of olive tree to salinity was reported by STEFANOUDAKI and co-workers (2009).

2.2.2. Olive oil cultivar susceptibility to temperature. 2.2.2.1. Peroxide and $\mathrm{p}$-anisidine values. - The fatty acid profile of olive oil is responsible for its relative stability (APARício et al., 1999; GuTIĖRREZ et al., 1999). The higher relative stability of olive oil when compared to that of other vegetable oils is not only due to the high oleic acid (monounsaturated) content and low polyunsaturated fatty acid content of the triacylglycerols but also to the levels of natural phenolic components with antioxidant activity (GómEZ-Alonso et al., 2003).

The increase of the $p$-anisidine values, attaining a maximum after 102 days of incubation suggests the formation of 2,4-decadienal, one of the volatile aldehydes formed during the degradation of hydroperoxides (WHITE, 1995).

2.2.3. Determination of total phenols. The variability in the total phenol amounts found in our samples is in accordance with those of VISSERS and co-workers (2004), which showed that the phenol concentration in olive oil depends on variety, climate, growth area, latitude and olive ripeness. Nevertheless, it is also noteworthy that low levels of phenols detected in the oil samples, always lower than those described for other olive oils obtained from different olive cultivars (Gómez-Alonso et al., 2003; LAVELli \& Bondesan, 2005). These results may be partly due to the method used for the determination of total phenols. Folin-Ciocalteu is considered a less specific and informative method than the quantification of individual phenols by HPLC (Gómez-Alonso et al., 2003), despite its regular utilization in the total phenol content determination after frying olive oils (PeLlegrini et al., 2001; ANDRIKopoulos et al., 2002). On the other hand, the low amounts of phenols detected in the present work, 
may also be due to other factors, given that Miguel and co-workers (2006), studying the cultivar influence on Cobrançosa olive oil oxidation, detected a three times higher total phenols content than those obtained in this work. Both olive oils were obtained from Cobrançosa cultivar but from different olive groves, in different years (2005 and 2006), and the production of the oils was carried out in different factories. It is known that virgin olive oils produced by direct-press or centrifugation methods have higher phenolic content (Mascitelli et al., 2007).

Maçanilha and Cobrançosa olive oils relative peroxidation similarity, and Maçanilha oil best capacity for preventing hydroperoxide degradation, may be attributed, among others, to the different relative proportions of phenols (hydroxytyrosol and tyrosol), and their derivatives in those olive oils (Papadopoulos \& Boskou, 1991; Baldioli et al., 1996; Rice-Evans et al., 1996; Vissers et al., 2004; CARRASCO-PANCORBO et al., 2005).

Studies have demonstrated that the individual phenolics within the polar phenolic fraction greatly varied in their stability when olive oils were stored at $60{ }^{\circ} \mathrm{C}$ (HRNCIRIK \& FRITSCHE, 2005). For example, it is reported that there is a great increase of tyrosol and hydroxytyrosol contents due to the hydrolysis of their complex derivatives in the first stage of storage, and a rapid loss of hydroxytyrosol as compared with that of tyrosol at the end of the storage (CINQUANTA et al., 1997).

2.2.4. DPPH scavenging test. The temperature used in our assay, $60{ }^{\circ} \mathrm{C}$, may be responsible for the transformation of the phenols into compounds with lower antioxidant activity. BRENES and co-workers (2002) and CARRASCO-PANCORBO and co-workers (2005) found a lost of hydroxytyrosol and its derivatives during heating of the olive oils, the diminution being more accentuated in linoleic acid rich olive oils than in the oleic acid rich ones. In addition, CARRASCO-PANCORBO and co-workers (2005) also referred that some phenols may be lost by oxidative coupling. At the same time, the absence of $\alpha$-tocopherol after 28 to 36 days of storage at $60{ }^{\circ} \mathrm{C}$ may also be responsible for the important decrease of the antioxidant activity.

\section{3. $\alpha$-Tocopherol content}

LEE and co-workers (2007) already reported the degradation of this vitamin, in different samples of vegetable oils, including olive oil. According to these authors, the degradation rate of tocopherols increased with the oil oxidation temperature, such degradation being more temperature-sensitive in olive oil than in sunflower and soybean oils. On the other hand, DEIANA and co-workers (2002) also detected that the decrease of $\alpha$-tocopherol was correlated to the increase of peroxide value as well as the initial amount of this vitamin greatly determined the pattern of the oxidation process: when less $\alpha$-tocopherol was present in the oil, the threshold value was reached sooner and the oxidation was enhanced. In the present work, the highest peroxide value obtained with Verdeal olive oil may be partly explained by the lowest levels of $\alpha$-tocopherol detected in this oil.

According to the classification of LAZZEZ and co-workers (2008), the relative high amounts of $\alpha$-tocopherol of the assayed samples, allow to consider these olive oils as of high quality ones. The variability of this component content in the assayed olive oils is not surprising since the olive variety, the geographic origin, the maturity stage of the olive and its conservation conditions have been shown to affect the total tocopherol amount (MiNGUEZ Mosquera \& Garrido Fernández, 1986; Deidda et al., 1994; Ben Lemime et al., 2006; Lazzez et al., 2008). 


\section{Conclusions}

This study demonstrated that olive oil stability and phenols and $\alpha$-tocopherol contents depend on the olive varieties from which they were obtained:

a) Cobrançosa and Maçanilha olive oils had some resistance to the hydroperoxides formation;

b) Verdeal and Maçanilha olive oils were more resistant to the formation of volatile aldehydes than Cobrançosa oils;

c) Cobrançosa oil showed higher phenols content than Maçanilha and Verdeal oils;

d) Cobrançosa and Maçanilha oils showed higher $\alpha$-tocopherol content than Verdeal oil.

\section{References}

Andrikopoulos, N.K., Kalogeropoulos, N., Faliera, A. \& Barbagianni, M.N. (2002): Performance on virgin olive oil and vegetable shortening during domestic deep-frying and pan-frying of potatoes. Int. J. Fd Sci. Technol., $37,177-190$.

A.O.C.S. (1989): Official methods and recommended practices. Vol. I, 4th ed., 2nd print, American Oil Chemists` Society, Champaign, ILL.

Aparício, R. \& Luna, G. (2002): Characterisation of monovarietal virgin olive oils. Eur. J. Lipid Sci. Technol., 104, $614-627$.

Aparício, R., Roda, L., Albi, M.A. \& Gutiérrez, F. (1999): Effect of various compounds on virgin olive oil stability measured by Rancimat. J. agric. Fd Chem., 47, 4150-4155.

Baldioli, M., Servilli, M., Perretti, G. \& Montedoro, G.F. (1996): Antioxidant activity of tocopherols and phenolic compounds of virgin olive oil. J. Am. Oil Chem. Soc., 73, 1589-1593.

BAwA, S. (2007): The role of glycemic index and glycemic load in the prevention and management of obesity. AgriFOOD Industry Hi-Tech., 18, 46-50.

Belitz, H-D. \& Grosch, W. (1999): Edible fats and oils. -in: Belitz, H-D. \& Grosch, W. (Eds) Food chemistry. $2^{\text {nd }}$ ed. Springer-Verlag, Berlin, Heidelberg, Germany, pp. 602-630.

Ben Lemime, S., Baccouri, B., TaAmalli, W., Abasa, L., Daoud, D. \& Zarrouk, M. (2006): Location effects on oxidative stability of Chétoui virgin olive oil. J. Fd Biochem., 30, 659-670.

Brenes, M., Garcia, A., Dobarganes, M.C., Velasco, J. \& Romero, C. (2002): Influence of thermal treatments simulating cooking processes on the polyphenol content in virgin olive oil. J. agric. Fd Chem., 50, 59625967.

Carrasco-Pancorbo, A., Cerretani, L., Bendini, A., Segura Carretero, A., del Carlo, M., Gallina-Toschi, T., Lercker, G., Compagnone, D. \& Fernández-Gutiérrez, A. (2005): Evaluation of the antioxidant capacity of individual phenolic compounds in virgin olive oil. J. agric. Fd Chem., 53, 8918-8925.

Cinquanta, L., Esti, M. \& La Notte, E. (1997): Evolution of phenolic compounds in virgin olive oil during storage. J. Am. Oil Chem. Soc., 74, 1259-1264.

Commission Regulation (1991): Off. J. Eur. Communities 2568/91, L248, 1-82.

Cunha, S.C., Carbal, S. \& Oliveira, M.B.P.P. (2005): Triacylglycerol profile by HPLC/ELSD as a discriminant parameter of varietal olive oils from Portugal. Ital. J. Fd Sci., 17, 447-454.

Cunha, S.C., Amaral, J.S., Fernandes, J.O. \& Oliveira, M.B.P.P. (2006a): Quantification of tocopherols and tocotrienols in Portuguese olive oils using HPLC with three different detection systems. J. agric. Fd Chem., 54, 3351-3356.

Cunha, S.C., Fernandes, J.O. \& Oliveira, M.B.P.P. (2006b): Quantification of free and esterified sterols in Portuguese olive oils by solid-phase extraction and gas chromatography-mass spectrometry. J. Chromat. A, 1128, 220227.

Di Bella, G., Maisano, R., La Pera, L., Lo Turco, V., Salvo, F. \& Dugo, G. (2007): Statistical characterization of Sicilian olive oils from the Peloritana and Maghrebian zones according to the fatty acid profile. J. agric. $F d$ Chem., 55, 6568-6574.

D’Imperio M., Dugo, G., Alfa, M., Mannina, L. \& Segre, A.L. (2007): Statistical analysis of Sicilian olive oils. Fd Chem., 102, 956-965. 
Damak, N., Bouaziz, M., Ayadi, M., Sayadi, S. \& Damak, M. (2008): Effect of the maturation process on the phenolic fractions, fatty acids, and antioxidant activity of the Chétoui olive fruit cultivar. J. agric. Fd Chem., 56, 1560-1566.

Deiana, M., Rosa, A., Cao, C.F., Pirisi, F.M., Bandino, G. \& Dessì, M.A. (2002): Novel approach to study oxidative stability of extra virgin olive oils: importance of $\alpha$-tocopherol concentration. J. agric. Fd Chem., 50, 43424346.

Deidda, P., Nieddu, V., Spino, D., Bandino, G., Orru, V., Solinas, M. \& Serraiocco, A. (1994): Olive quality in relation to environmental conditions. Acta Hortic., 356, 354-357.

Gama, P., Casal, S., Oliveira, B. \& Ferreira, M.A. (2000): Development of an HPLC/diode-array fluorimetric detector method for monitoring tocopherols and tocotrienols in edible oils. J. L. Chromat. R. T., 23, 30113022 .

Gómez-Alonso, S., Fregapane, G., Salvador, M.D. \& Gordon, M.H. (2003): Changes in phenolic composition and antioxidant activity of virgin olive oil during frying. J. agric. Fd Chem., 51, 667-672.

GutiérRez, F., JimÉnez, B., Ruiz, A. \& Albi, M.A. (1999): Effect of olive ripeness on the oxidative stability of virgin olive oil extracted from the varieties of Picual and Hojiblanca and on the different components involved. $J$. agric. Fd Chem., 47, 121-127.

Haddada, F.M., Manaï, H., Oueslati, I., Daoud, D., Sánchez, J., Osorio, E. \& Zarrouk, M. (2007): Fatty acid, triacylglycerol, and phytosterol composition in six Tunisian olive varieties. J. agric. Fd Chem, 55, 1094110946.

Hrncirik, K. \& Fritsche, S. (2005): Relation between the endogenous antioxidant system and the quality of extra virgin olive oil under accelerated storage conditions. J. agric. Fd Chem., 53, 2103-2110.

Kirsch, C., Takamiya-Wik, M., Reinold, S., Hahlbrock, K. \& Somssich, I.E. (1997): Rapid, transient and highly localized induction of plastidial $\omega-3$ fatty acid desaturase mRNA at fungal infection sites in Petroselinum crispum. Proc. Natl Acad. Sci. USA, 94, 2079-2084.

LaVelli, V. \& Bondesan, L. (2005): Secoiridoids, tocopherols, and antioxidant activity of monovarietal extra virgin olive oils extracted from destoned fruits. J. agric. Fd Chem., 53, 1102-1107.

Lazzez, A., Perri, E., Caravita, M.A., Khlif, M. \& Cossentini, M. (2008): Influence of olive maturity stage and geographical origin on some minor components in virgin olive oil of the Chammali variety. J. agric. Fd Chem., 56, 982-988.

Lee, J., Lee, Y. \& Chое, E. (2007): Temperature dependence of the autooxidation and antioxidants of soybean, sunflower, and olive oil. Eur. Fd Res. Technol., 226, 239-246.

Leitão, F., Potes, F., Calado, L. \& Almeida, F.J. (1986): Descrição de 22 variedades de oliveira cultivadas em Portugal. (Description of 22 varieties of olive trees grown in Portugal.) MAPA/DGPA, Lisboa, 111 pages.

Leon, L., de la Rosa, R., Gracia, A., Barranco, D. \& Rallo, L. (2008): Fatty acid composition of advanced olive selections obtained by crossbreeding. J. Sci. Fd Agric., 88, 1921-1926.

Maia, L.C., Pereira, J.A., Andrade, P.B., Seabra, R.M. \& Oliveira, M.B.P.P. (2007): Evaluation of a numerical method to predict the polyphenols content in monovarietal olive oils. Fd Chem., 102, 976-983.

Maia, L., CAsal, S. \& Oliveira, M.B.P.P. (2008): Validation of a micromethod for quantification of lutein and $\beta$-carotene in olive oil. J. L. Chromat. R. T., 31, 733-742.

Mailer, R. (2006): Testing olive oil quality: chemical and sensory methods. Primefact, 231, 1-5.

Mailer, R., Conlan, D. \& Ayton, J. (2005): Olive oil (harvest timing for optimal olive oil quality). A report for the Rural Industries Research and development Corporation. RIRDC Publication No 05/103; RIRDC Project N $^{\circ}$ DAN-197A. Rural Industries Research and Development Corporation. Australian Government, pp. 1-67.

Mascitelli, L., Pezzeta, F. \& Sullivan, J.L. (2007): Antioxidant effects in vivo of interactions of iron from with olive oil polyphenols: potential implications for future study designs. AgriFOOD Industry Hi-Tech., 18, 9-11.

Matos, L.C., Cunha, S.C., Amaral, J.S., Pereira, J.A., Andrade, P.B., Seabra, R.M. \& Oliveira, M.B.P.P. (2007): Chemometric characterization of three varietal olive oils (Cvs. Cobrançosa, Madural and Verdeal Transmontana) extracted from olives with different maturation indices. Fd Chem., 102, 406-414.

Miguel, M., Dandlen, S., Teixeira, A., Ramalho, L., Costa, F., Venâncio, F. \& Neves, M. (2006): Influência da cultivar na oxidação do azeite. (Cultivar's influence on olive oil oxidation.) Melhoramento, 41, 192-197.

Minguez Mosquera, M.I. \& Garrido Fernández, F. (1986): Composición y evaluación de clorofilas y carotenoides durante el desarollo y maduración de los frutos del olivo. (Composition and evaluation of chlorophylls and carotenoids during development and maturation of olive fruits.) Grasas y Aceites, 37, 337-342.

OKogeri, O. \& TAsioula-Margari, M. (2002): Changes in phenolic compounds and $\alpha$-tocopherol of virgin olive oil during storage. J. agric. Fd Chem., 50, 1077-1080. 
Papadopoulos, G.K. \& Boskou, D. (1991): Antioxidant effect of natural phenols on olive oil. J. Am. Oil Chem. Soc., $68,669-671$.

Pellegrini, N., Visioli, F., Buratti, S. \& Brighenti, F. (2001): Direct analysis of total antioxidant activity of olive oil and studies on the influence of heating. J. agric. Fd Chem., 49, 2532-2538.

Pereira, J.A., Casal, S., Bento, A. \& Oliveira, M.B.P.P. (2002): Influence of olive storage period on oil quality of three Portuguese cultivars of Olea europaea, Cobrançosa, Madural, and Verdeal Transmontana. J. agric. Fd Chem., 50, 6335-6340.

Pereira, J.A., Alves, M.R., Casal, S. \& Oliveira, M.B.P.P. (2004): Effect of olive fruit fly infestation on the quality of olive oil from cultivars Cobrançosa, Madural and Verdeal Transmontana. Ital. J. Fd Sci., 16, 355-365.

Portugal Standard (1984): Gorduras e óleos comestíveis. Determinação do índice de p-anisidina. (Edible fats and oils. Determining the $p$-anisidine value.) NP-1819, DR III Série $n^{\circ} 103$, de 1984-05-04

Rice-Evans, C.A., Miller, N.J. \& Paganga, G. (1996): Structure-antioxidant activity relationships of flavonoids and phenolic acids. Free Radical Biol. Med., 20, 933-956.

Simões-lopes, P., Gouveia, J.B., Peres, F., Gouveia, C., Henriques, L., Pinheiro-Alves, M.C. \& Freitas, A.M. (2006): Qualidade de azeites virgens portugueses com denominação de origem protegida. (Quality of Portuguese virgin olive oils with protected designation of origin.) Melhoramento, 41, 210-216.

Stefanoudaki, E., Williams, M., Chartzoulakis, K. \& Harwood, J. (2009): Olive oil qualitative parameters after orchard irrigation with saline water. J. agric. Fd Chem., 57, 1421-1425.

UPCHURCH, R.G. (2008): Fatty acid unsaturation, mobilization, and regulation in the response of plants to stress. Biotechnol. Lett., 30, 967-977.

Vissers, M.N., Zock, P.L. \& Katan, M.B. (2004): Bioavailability and antioxidant effects of olive oil phenols in human: a review. Eur. J. clin. Nutr., 58, 955-965.

White, P.J. (1995): Conjugated diene, anisidine value and carbonyl value analyses. -in: WARNER, K. \& EsKIN, N.A.M. (Eds) Methods to assess quality and stability of oils and fat-containing foods. AOCS Press, Champaign, IL. pp. $159-178$.

Zou, J., Rodriguez-Zas, S., Aldea, M., Li, M., Zhu, J., Gonzalez, D.O., Vodkin, L.O., Delucia, E. \& Clough, S.J. (2005): Expression profiling soybean response to Pseudomonas syringae reveals new defense-related genes and rapid HR-specific downregulation of photosynthesis. Mol. Pl.-Microbe Interact., 18, 1161-1174. 